\title{
A near IR di-styryl BODIPY-based ratiometric fluorescent chemosensor for $\mathbf{H g}$ (II)
}

\author{
Serdar Atilgan ${ }^{\mathrm{a}, \mathrm{b}, *}$, Ilker Kutuk $^{\mathrm{a}}$, Tugba Ozdemir ${ }^{\mathrm{c}}$ \\ a Department of Chemistry, Middle East Technical University, Ankara TR-06531, Turkey \\ ${ }^{\mathrm{b}}$ Department of Chemistry, Suleyman Demirel University, Isparta 32000, Turkey \\ ${ }^{\mathrm{c}}$ UNAM-Institute of Materials Science and Nanotechnology and Department of Chemistry, Bilkent University, Ankara TR-06800, Turkey
}

\section{A R T I C L E I N F O}

\section{Article history:}

Received 29 August 2009

Revised 26 November 2009

Accepted 4 December 2009

Available online 11 December 2009

\begin{abstract}
A B S T R A C T
A novel BODIPY-based near-IR emitting probe as a selective and sensitive fluorophore for $\mathrm{Hg}(\mathrm{II})$ is synthesized. This versatile BODIPY fluorophore is functionalized for long wavelength emission at the 3 and 5 positions via a condensation reaction in which two dithiodioxomonoaza-based crown-containing phenyl units are conjugated to the BODIPY core as a chelating unit. This designed fluorophore, employing an ICT sensor can be used effectively to detect $\mathrm{Hg}(\mathrm{II})$ cations by way of a hypsochromic shift $(\sim 90 \mathrm{~nm})$ in both the absorption and emission spectra.
\end{abstract}

(c) 2009 Elsevier Ltd. All rights reserved.
Mercury is a toxic heavy metal and is a hazardous environmental contaminant. It is a considerably dangerous metal to human life and ecology even at low concentrations. ${ }^{1}$ Problems arise in aquatic systems in which anaerobic organisms can transform the elemental and inorganic forms of mercury into organometallic mercury, such as methyl mercury, ${ }^{2}$ which can easily enter the food chain and rapidly concentrate in the upper levels, especially in large edible fishes. ${ }^{3}$ Thus, it can easily transfer to the human body and can cause serious health concerns such as brain damage, ${ }^{4}$ DNA damage, ${ }^{5}$ various cognitive and motion disorders, ${ }^{6}$ and Minamata disease. ${ }^{7}$ Considering its toxicity, several analytical techniques have been employed such as atomic absorption spectroscopy ${ }^{8}$ and inductively coupled plasma mass spectroscopy ${ }^{9}$ to detect mercury. However, these current techniques demand very complicated and expensive instrumentation as well as multistep sample preparation. Therefore, emphasis has been placed on the synthesis and design of fluorescent sensors ${ }^{10}$ which offer a promising approach for mercury ion detection in terms of sensitivity, selectivity, and low cost. $^{11}$

To date, a number of fluorescent ionophores for mercury ions have been reported based on different fluorophores such as fluorescein, ${ }^{12}$ rhodamine, ${ }^{13}$ naphthalimide, ${ }^{14}$ boradiazaindacene ${ }^{15}$ (BODIPY). However, most of these reported fluorescent ionophores work in the visible region of the spectrum, and so far only a few examples that have lower energy emission in the near-IR region have been described. Recently, chemosensors that absorb or emit in the near-IR region have become of significant interest for biological and environmental use. In particular, the absence or significant reduction of background absorption, fluorescence, and light scattering, and the availability of low-cost sources of irradiation make

\footnotetext{
* Corresponding author. Tel.: +90 312210 5153; fax: +90 3122103200

E-mail address: atilganserdar@hotmail.com (S. Atilgan).
}

these chemosensors preferable for biological application. ${ }^{16}$ On the other hand, coordination of mercury cations often cause a 'turn-off' fluorescence response because, like other heavy metal cations, mercury is a fluroescence quencher. ${ }^{17}$ Therefore, for an ionophore designed to select mercury cations, fluorescence enhancement (turn-on) is preferable to fluorescence quenching (turn-off).

To date, a few near-IR emitting fluorescent chemosensors have been presented to achieve a ratiometric analysis of mercury cations. ${ }^{18}$ Herein, we present a new chemosensor with a turn-on near-IR optical response for ratiometric mercury detection. We chose a promising red-emitting dye, di-styryl BODIPY, ${ }^{19}$ as the fluorophore. So far, the versatile BODIPY dye has been utilized as an active fluorophore in the fields of chemosensors, ${ }^{20}$ logic gates, ${ }^{21}$ light harvesting systems, ${ }^{22}$ energy transfer cassettes, ${ }^{23}$ dye-sensitized solar cells, ${ }^{24}$ polymers, ${ }^{25}$ and in OLED applications ${ }^{26}$ benefitting from properties such as high quantum yields (typically 0.61.0), large extinction coefficients $\left(60,000-80,000 \mathrm{M}^{-1} \mathrm{~cm}^{-1}\right)$ and the photostability of these fluorophores. These novel intriguing di-styryl (DS)-BODIPY fluorophores, derived from successful modification of the BODIPY core, also display several applications in diverse fields such as sensitizers for photodynamic therapy ${ }^{27}$ and as a chemosensor ${ }^{28}$ for zinc cations with red shift properties in the absorption and emission spectra.

The synthesis of our chemosensor is shown in Scheme 1. BODIPY fluorophore, $\mathbf{1}$, was synthesized according to the procedure published previously ${ }^{19}$ by condensing $p$-tert-butyl benzaldehyde with 3-ethyl-2,4-dimethyl-pyrrole (Supplementary data). It is known that $\mathrm{Hg}^{2+}$ is a soft acid and the use of soft donor atoms as receptor units result in good selectivity for $\mathrm{Hg}^{2+}$. Thus the wellknown $\mathrm{Hg}^{2+}$ selective ligand, dithia-dioxa-aza macrocycle $\mathbf{2}^{15 \mathrm{~d}, 20 \mathrm{~d}}$ was chosen as a receptor. We obtained compound $\mathbf{2}$ by reaction between $N, N$-bis(bromoethyl)aniline and 2,2-[ethane-1,2-diylbis(oxy)]diethanothiol in the presence of $\mathrm{Cs}_{2} \mathrm{CO}_{3}$ (Supplementary 

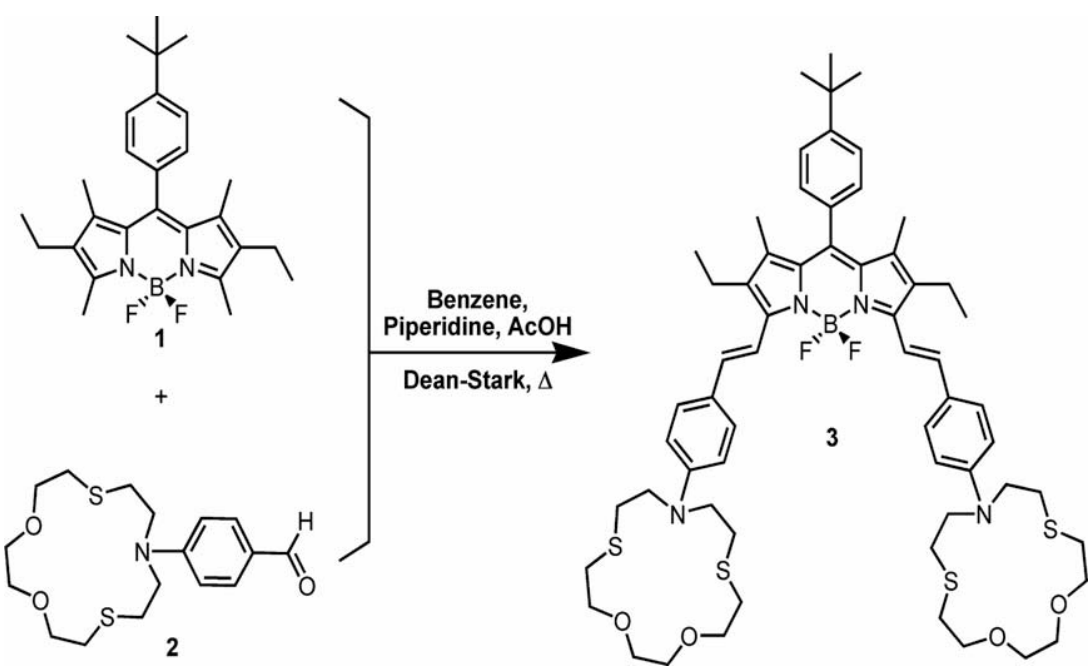

Scheme 1. Synthesis of the near-IR emitting, double chelated DS-BODIPY-based, chemosensor 3.

data) followed by a Vilsmeier-Haack type reaction to yield compound 2. To obtain chemosensor $\mathbf{3}$, compound $\mathbf{2}$ was utilized for extended conjugation at the methyl groups at the 3,5 positions on the BODIPY core of $\mathbf{1}$, leading to longer wavelengths in the visible red region for the BODIPY fluorophore. Compound 3, was isolated and characterized by ${ }^{1} \mathrm{H},{ }^{13} \mathrm{C}$ NMR, and MALDI-TOF (Supplementary data).

Our model consists of two chelating substituents on the BODIPY core for mercury cation sensing. These two substituents on the BODIPY core also enabled an advantageous ICT mechanism. The absorption spectrum of the metal-free form of the dye $\mathbf{3}$ was acquired in THF and showed a band at $720 \mathrm{~nm}$. The addition of $\mathrm{Hg}\left(\mathrm{ClO}_{4}\right)_{2}$ to a solution of the dye in THF caused the appearance of a new band at $630 \mathrm{~nm}$ and a simultaneous disappearance of the band at $720 \mathrm{~nm}$ (Fig. 1). This new band was blue-shifted by $90 \mathrm{~nm}$ and was observed as a color change from green to blue (can be detected with the naked-eye). This large hypsochromic shift with an isosbestic point at $670 \mathrm{~nm}$ clearly indicates that coordination of one mercury cation to the fluorophore $\mathbf{3}$ kinetically favored the coordination of a second mercury cation instead of the metal-free form of dye 3 . Coordination of cations to nitrogen donor atoms of the dithia-dioxa-aza unit block the ICT process on the BODIPY fluorophore, observed as a spectral shift in both the

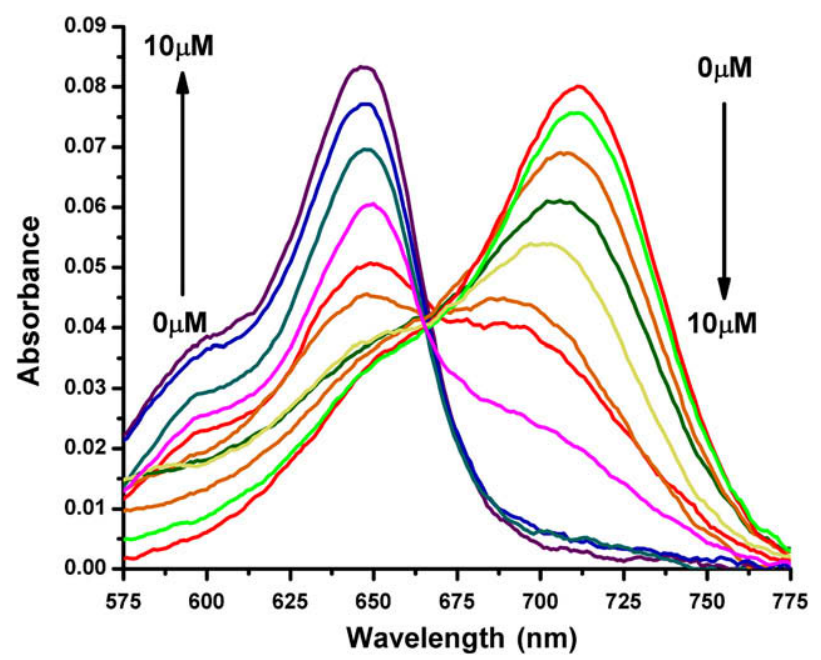

Figure 1. Absorption spectra of DS-BODIPY $(1.5 \mu \mathrm{M})$ in the presence of an increasing concentration of $\mathrm{Hg}^{2+}$ (cation concentrations; $0,0.5,0.75,1.0,1.5,2.0$, $2.5,4.0,5.0,7.5,10 \mu \mathrm{M})$ in THF. absorption and emission spectra of the fluorophore (Figs. 1 and 4). The ICT process gave rise to two distinct absorption and emission wavelengths. A ratiometric analysis for $\mathrm{Hg}$ (II) cations is presented with the formation of these two distinct wavelengths. Meanwhile addition of any metal ions other than $\mathrm{Hg}^{2+}$, caused no change in the absorption maxima (Supplementary data, see Fig. S1).

The fluorescence spectrum was also recorded with this highly mercury selective dye 3 in THF (Fig. 2). The ICT process from the crown unit to the BODIPY core leads to strong fluorescence quenching. Thus, chemosensor 3, itself shows very weak emission intensity at $740 \mathrm{~nm}$ (Fig. 2). The coordination of $\mathrm{Hg}^{2+}$ to the receptors resulted in a reduction of the electron-donating ability of the two amino groups conjugated to the BODIPY core, and hence the receptor showed a $90 \mathrm{~nm}$ blue shift with a strong fluorescence emission intensity (Fig. 2). Moreover, due to the selectivity of the receptor, metal ions other than $\mathrm{Hg}^{2+}$ produced no change in emission spectra and absorption spectra.

The fluorescence response of the dye in the presence of $\mathrm{Hg}^{2+}$ $(10 \mu \mathrm{M})$ and a competing cation $(20 \mu \mathrm{M})$ is presented in Figure 3. The fluorescence intensity of the dye was unaffected and the presence of a metal other than $\mathrm{Hg}^{2+}$ did not influence the coordination of $\mathrm{Hg}^{2+}$ to the receptor moiety.

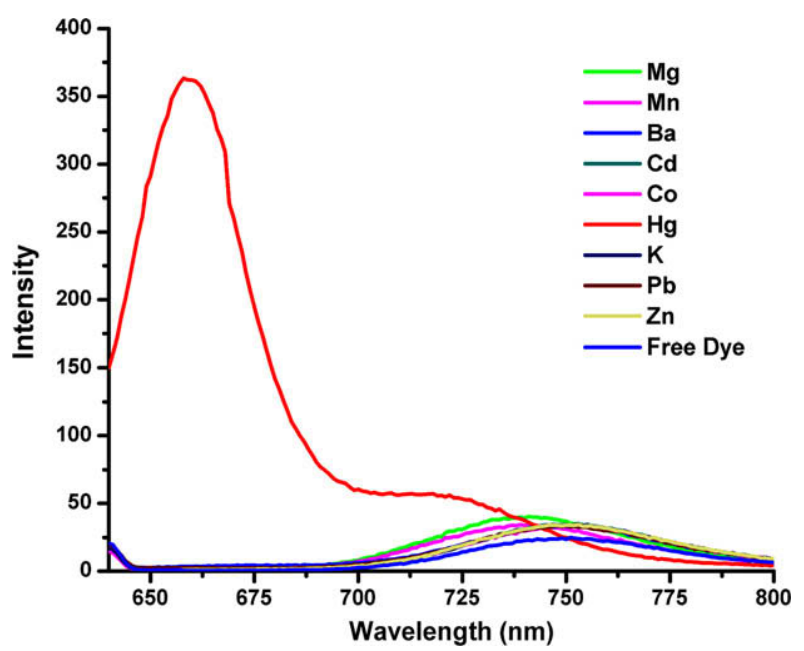

Figure 2. Change in the emission spectrum of DS-BODIPY $(1.5 \mu \mathrm{M})$ in response to different cations (cation concentration $10.0 \mu \mathrm{M}$ in THF). Excitation wavelength was $640 \mathrm{~nm}$ with a slit width of $2.5 \mathrm{~nm}$. 


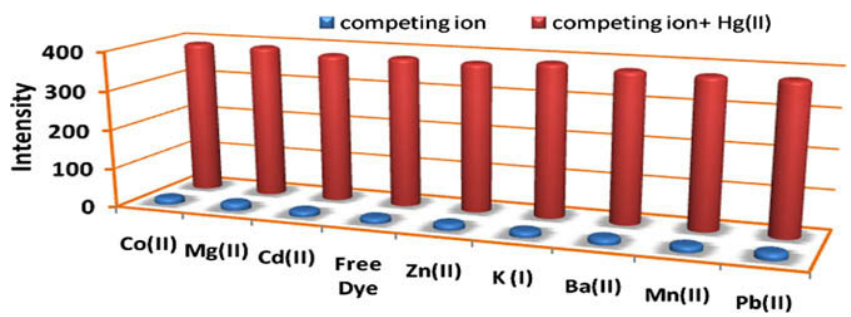

Figure 3. The fluorescence intensity response of DS-BODIPY $(1.5 \mu \mathrm{M})$ with $20 \mu \mathrm{M}$ of a competing metal followed by addition of $10 \mu \mathrm{M} \mathrm{Hg}^{+2}$ in THF. Excitation wavelength was $640 \mathrm{~nm}$ with a slit width of $2.5 \mathrm{~nm}$.

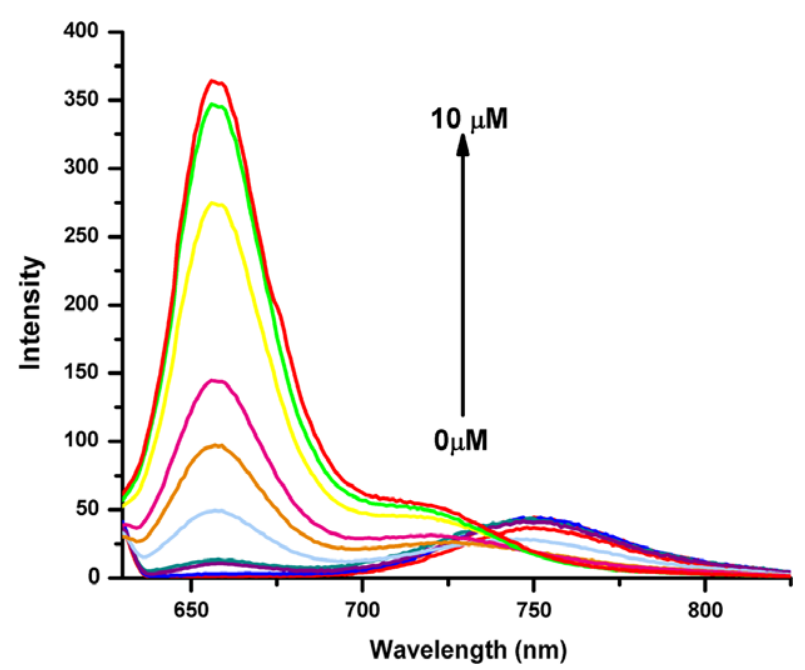

Figure 4. Emission spectra of the chemosensor 3, at increasing concentrations of $\mathrm{Hg}^{2+}$ (cation concentrations $0,0.5,0.75,1.0,1.5,2.0,2.5,4.0,5.0,7.5,10 \mu \mathrm{M}$ ) in THF. Excitation wavelength was $630 \mathrm{~nm}$ with a slit width of $2.5 \mathrm{~nm}$.

A titration experiment was also conducted in order to observe ratiometric analysis and also to calculate the binding constant $\left(K_{\mathrm{d}}\right)$ of the chemosensor 3 with $\mathrm{Hg}^{2+}$. The stoichiometry between dye 3 and $\mathrm{Hg}^{2+}$ is confirmed by Hill plot analysis, Figure 4 (details in Supplementary data). ${ }^{29}$ As expected, the sigmoidal curve (Fig. 3 in Supplementary data) clearly shows a $1: 2$ stoichiometry between 3: $\mathrm{Hg}^{2+}$ with a dissociation constant of $1.8 \times 10^{-6} \mathrm{M}^{2}$.

In conclusion, we have presented a highly selective and sensitive BODIPY-based near-IR emitting chemosensor for $\mathrm{Hg}^{2+}$ over other competing cations even at low concentration. This chemosensor can be used as an analytical tool for qualitative monitoring, and quantitative detection of $\mathrm{Hg}^{2+}$. Moreover a large hypsochromic shift (approx. $90 \mathrm{~nm}$ ) is seen with the coordination of $\mathrm{Hg}^{2+}$ in both the absorption and emission spectrum. Analyses of the chemosensor were carried out in THF to demonstrate our modeling as an alternative chemosensor for mercury cation in the near-IR region. It may be that this work will influence the development of new near-IR emitting BODIPY-based chemosensors and biologically important water soluble near-IR emitting chemosensors.

\section{Acknowledgment}

The authors thank Professor Dr. Engin U. Akkaya for fruitful discussions.

\section{Supplementary data}

Supplementary data (syntheses, experimental details, ${ }^{1} \mathrm{H},{ }^{13} \mathrm{C}$ NMR spectra and additional spectroscopic data, figures used to cal- culate binding constants and stoichiometry and digital photographs) associated with this Letter can be found, in the online version, at doi:10.1016/j.tetlet.2009.12.025.

\section{References and notes}

1. (a) Fitzgerald, W. F.; Lamborg, C. H.; Hammerschmidt, C. R. Chem. Rev. 2007, 107, 641; (b) Harris, H. H.; Pickering, I. J.; George, G. N. Science 2003, 301, 1203 (c). Chem. Rev. 2008, 108, 3443; (d) Renzoni, A.; Zino, F.; Franchi, E. Environ. Res. Sect., A 1998, 77, 68.

2. Mason, R. P.; Fitzgerald, W. F. Nature 1990, 347, 457.

3. (a) Boening, D. W. Chemosphere 2000, 40, 1335; (b) Trudel, M.; Rasmussen, J. B. Environ. Sci. Technol. 1997,31,1716; (c) Clarkson, T.W.J.Trace Elem. Exp. Med. 1998 11, 303; (d) Frodello, J. P.; Romeo, M.; Viale, D. Environ. Pollut. 2000, 108, 447.

4. Chapman, L. A.; Chan, M. H. Toxicology 1999, 132, 167.

5. Tchounwou, P. B.; Avensu, W. K.; Ninashvili, N.; Sutton, D. Environ. Toxicol. 2003, $18,149$.

6. Takeuchi, T.; Morikawa, N.; Matsumoto, H.; Shiraishi, Y. Acta Neuropathol. 1962 $2,40$.

7. Harada, M. Crit. Rev. Toxicol. 1995, 25, 1.

8. Bloom, N.; Fitzgerald, W. F. Anal. Chim. Acta 1988, 208, 151.

9. Huang, C. W.; Jiang, S. J. J. Anal. Atom. Spectrom. 1993, 8, 681.

10. (a) Czarnik, A. W. Fluorescent Chemosensors for Ion And Molecule Recognition ACS Symposium Series 538; American Chemical Society: Washington, DC, 1992; p 235.; (b) Czarnik, A. W. Acc. Chem. Soc. 1994, 27, 302; (c) Valeur, B.; Leray, I. Coord. Chem. Rev. 2000, 205, 3; (d) de Silva, A. P.; Gunaratne, H. Q. N.; Gunnlaugsson, T.; Huxley, A. J. M.; McCoy, C. P.; Rademacher, J. T.; Rice, T. E. Chem. Rev. 1997, 97, 1515; (e) Callan, J. F.; de Silva, A. P.; Magri, D. C. Tetrahedron 2005, 61, 8551.

11. (a) Bhalla, V.; Tejpal, R.; Kumar, M.; Puri, R. K.; Mahajan, R. K. Tetrahedron Lett 2009, 50, 2649; (b) Lee, D.-N.; Kim, G.-J.; Kim, H.-J. Tetrahedron Lett. 2009, 50 , 4766; (c) Kim, S. H.; Song, K. C.; Ahn, S.; Kang, Y. S.; Chang, S.-K. Tetrahedron Lett. 2006, 47, 497; (d) Choi, M. G.; Kim, Y. H.; Namgoong, J. E.; Chang, S.-K. Chem. Commun. 2009, 3560.

12. (a) Nolan, E. M.; Lippard, S. J. J. Am. Chem. Soc. 2003, 125, 14270; (b) Yang, X.-F.; Lia, Y.; Bai, Q. Anal. Chim. Acta 2007, 584, 95; (c) Yoon, S.; Miller, E. W.; He, Q. Do, P. K.; Chang, C. J. Angew. Chem., Int. Ed. 2007, 46, 6658; (d) Santra, M.; Ryu, D.; Chatterjee, S.; Ko, S. K.; Shin, I.; Ahn, K. H. Chem. Commun. 2009, 2115.

13. (a) Yang, Y.-K.; Yook, K.-J.; Tae, J. J. Am. Chem. Soc. 2005, 127, 16760; (b) Zheng, H.; Qian, Z.-H.; Xu, L.; Yuan, F.-F.; Lan, L.-D.; Xu, J.-G. Org. Lett. 2006, 8, 859; (c) Lee, M. H.; Lee, S. J.; Jung, J. H.; Lim, H.; Kim, J. S. Tetrahedron 2007, 63, 12087; (d) Chen, X.; Nam, S.-W.; Jou, M. J.; Kim, Y.; Kim, S.-J.; Park, S.; Yoon, J. Org. Lett. 2008, 10, 5235 .

14. (a) Rurack, K.; Resch-Genger, U.; Bricks, J. L.; Spieles, M. Chem. Commun. 2000, 2103; (b) Guo, X.; Qian, X.; Jia, L. J. Am. Chem. Soc. 2004, 126, 2272; (c) Wang, J.; Qian, X. Chem. Commun. 2006, 109.

15. (a) Rurack, K.; Kollmannsberger, M.; Resch-Genger, U.; Daub, J. J. Am. Chem. Soc 2000, 122, 968; (b) Yuan, M.; Li, Y.; Li, J.; Li, C.; Liu, X.; Lv, J.; Xu, J.; Liu, H.; Wang, S.; Zhu, D. Org. Lett. 2007, 9, 2313; (c) Wang, J. B.; Qian, X. H. Org. Lett. 2006, 8, 3721; (d) Coskun, A.; Akkaya, E. U. J. Am. Chem. Soc. 2006, 128, 14474.

16. Akkaya, E. U.; Turkyılmaz, S. Tetrahedron Lett. 1997, 38(25), 4513.

17. Yoon, J.; Ohler, N. E.; Vance, D. H.; Aumiller, W. D.; Czarnik, A. W. Tetrahedron Lett. 1997, 38, 3845.

18. (a) Coskun, A.; Yilmaz, M. D.; Akkaya, E. U. Org. Lett. 2007, 9, 607; (b) Zhu, M. Yuan, M. J.; Liu, X. F.; Xu, J. L.; Lv, J.; Huang, C. S.; Liu, H. B.; Li, Y. L.; Wang, S.; Zhu, D. B. Org. Lett. 2008, 10, 1481.

19. Dost, Z:; Atilgan, S.; Akkaya, E. U. Tetrahedron 2006, 62, 8484

20. (a) Coskun, A.; Akkaya, E. U. J. Am. Chem. Soc. 2005, 127, 10464; (b) Zeng, L.; Miller, E. W.; Pralle, A.; Isacoff, E. Y.; Chang, C. J. J. Am. Chem. Soc. 2006, 128, 10; (c) Guliyev, R.; Coskun, A.; Akkaya, E. U. J. Am. Chem. Soc. 2009, 131, 9007; (d) Guliyev, R.; Buyukcakir, O.; Sozmen, F.; Bozdemir, O. A. Tetrahedron Lett. 2009, 50, 5139; (e) Gabe, Y.; Yrano, Y.; Kikuchi, H.; Kojima, H.; Nagano, T. J. Am. Chem. Soc. 2004, 126, 3357

21. (a) Coskun, A.; Deniz, E.; Akkaya, E. U. Org. Lett. 2005, 7, 5187; (b) Ozlem, S. Akkaya, E. U. J. Am. Chem. Soc. 2009, 131, 48

22. (a) Yilmaz, M. D.; Bozdemir, O. A.; Akkaya, E. U. Org. Lett. 2006, 8, 2871; (b) Alamiry, M. A. H.; Harriman, A.; Mallon, L. J.; Ulrich, G.; Ziessel, R. Eur. J. Org. Chem. 2008, 2774.

23. (a) Burghart, A.; Thoresen, L. H.; Chen, J.; Burgess, K.; Bergstrom, F.; Johansson, L. B.-A. Chem. Commun. 2000, 2203; (b) Goze, C.; Ulrich, G.; Ziessel, R. Org. Lett. 2006, 8, 4445.

24. (a) Hattori, S.; Ohkubo, K.; Urano, Y.; Sunahara, H.; Nagano, T.; Wada, Y.; Tkachenko, N. V.; Lemmetyinen, H.; Fukuzumi, S. J. Phys. Chem. B 2005, 109, 15368; (b) Ela, S. E.; Yilmaz, M. D.; Icli, B.; Dede, Y.; Icli, S.; Akkaya, E. U. Org. Lett. 2008, 10, 3299.

25. Cakmak, Y.; Akkaya, E. U. Org. Lett. 2009, 11, 84.

26. Ozdemir, T.; Atilgan, S.; Kutuk, I.; Yildirim, L. T.; Tulek, A.; Bayindir, M.; Akkaya, E. U. Org. Lett. 2009, 11, 2105.

27. Atilgan, S.; Ekmekçi, Z.; Dogan, A. L.; Guc, D.; Akkaya, E. U. Chem. Commun. 2006, 4398.

28. Atilgan, S.; Ozdemir, T.; Akkaya, E. U. Org. Lett. 2008, 10, 4065.

29. The binding constant determination and Hill plot analysis were determined as follows, see: Peng, X.; Du, J.; Fan, J.; Wang, J.; Wu, Y.; Zhao, J.; Sun, S.; Xu, T. J. Am. Chem. Soc. 2007, 129, 1500. 